\title{
Analisis Kualitas Hidup Pasien Diabetes Melitus Tipe Berdasarkan Pola Peresepan Antidiabetik dan Komplikasi
}

\author{
Analysis of Quality of Life of Type 2 Diabetes Patients Based on Antidiabetic Prescribed and \\ Complications
}

\author{
Pande Made Desy Ratnasari ${ }^{1 *}$, Tri Murti Andayani ${ }^{2}$, Dwi Endarti ${ }^{2}$ \\ 1. Magister Farmasi Klinik, Fakultas Farmasi, Universitas Gadjah Mada,Yogyakarta \\ 2. Fakultas Farmasi, Universitas Gadjah Mada,Yogyakarta \\ Submitted: 16-05-2019 Revised: 31-07-2019 \\ Accepted: 27-12-2019 \\ Korespondensi : Pande Made Desy Ratnasari : Email : desypandemade@gmail.com
}

\begin{abstract}
ABSTRAK
Diabetes melitus (DM) tipe 2 merupakan penyakit metabolik kronik yang membutuhkan terapi seumur hidup untuk mengontrol glukosa darah. Penggunaan jenis terapi dengan mekasime kerja yang berbeda dalam jangka waktu panjang berpotensi menimbulkan ketidaknyamanan serta efek samping obat yang dapat berpengaruh terhadap kualitas hidup. Tujuan penelitian adalah untuk mengetahui perbedaan kualitas hidup pasien DM tipe 2 berdasarkan pola peresepan antidiabetik dan komplikasi Di Instalasi Rawat Jalan Poliklinik Penyakit Dalam RSUD Panembahan Senopati Bantul Yogyakarta pada bulan September 2017. Jenis penelitian adalah observational dengan rancangan cross sectional. Pengambilan data penelitian menggunakan kuesioner Diabetes Quality of Life Clinical Trial Quessionaire (DQLCTQ) serta berdasarkan rekam medik pasien. Penelitian ini melibatkan 200 pasien DM tipe 2 yang memperoleh antidiabetik minimal 3 bulan sebelum penelitian, berusia $\geq 18$ tahun, menyetujui inform concent serta bersedia mengisi kuesioner. Data sosiodemografi, pola peresepan dan komplikasi digambarkan secara deskriptif. Perbedaan kualitas hidup berdasarkan pola peresepan dan komplikasi dianalisis menggunakan uji Kruskal Wallis, lalu selanjutnya dianalisis menggunakan uji post hoc dengan Mann Whitney. Hasil penelitian menunjukkan sebagian besar pasien memperoleh peresepan kombinasi oral dengan insulin (48,5\%) dan sebesar 19,5\% menderita komplikasi makrovaskuler. Rata-rata nilai kualitas hidup pasien DM tipe 2 adalah 65,7. Terdapat perbedaan kualitas hidup berdasarkan peresepan antidiabetik pada domain kepuasan pengobatan $(p=0,000)$ antara kelompok monoterapi oral dengan kombinasi oral dan insulin $(p=0,000)$ serta monoterapi insulin dengan kombinasi oral dan insulin $(p=0,002)$. Terdapat perbedaan kualitas hidup berdasarkan komplikasi pada domain kesehatan mental $(p=0,003)$ antara komplikasi makrovaskuler dengan mikrovaskuler $(p=0,011)$ serta antara komplikasi mikrovaskuler dengan tanpa komplikasi $(p=0,001)$.

Kata kunci: DM tipe 2; kualitas hidup; pola peresepan antidiabetik; komplikasi
\end{abstract}

\section{ABSTRACT}

Type 2 diabetes mellitus (T2DM) is a chronic metabolic disease that requires lifelong therapy to control blood glucose. The long term use and different mechanism of action antidiabetic have the potential cause side effects and discomfort that affects the quality of life. This study aimed to determine differences in the quality of life of patients with T2DM based on antidiabetic prescribed and complications at the Outpatient of Panembahan Senopati Bantul Yogyakarta Hospital in September 2017. This research is observational with a cross-sectional design. Quality of life data is taking concurrently using the Diabetes Quality of Life Clinical Trial Questionnaire and patient's medical record. This study involved 200 T2DM patients who received antidiabetic at least 3 months before study, aged $\geq 18$ years and agreed to inform concent. Sociodemographic data, antidiabetic prescribed and complications were described descriptively. Differences in the quality of life based on antidiabetic prescribed and complications using the Kruskal Wallis test which was further analyzed using the post hoc by Mann Whitney test. The results showed the majority of patients received oral combination with insulin (48.5\%) and dominated by macrovascular complications (19.5\%). The average value of patient's quality of life is 65.7 . There was difference quality of life based on antidiabetic prescribed in the domain of treatment satisfaction $(p=0.000)$ between oral monotherapy with combination of oral and insulin $(p=0.000)$ and insulin monotherapy with combination of oral and insulin $(p=0.002)$. There were differences in quality of life based on complications in the mental 
health domain $(p=0.003)$ between macrovascular and microvascular $(p=0.011)$ and between microvascular and without complications ( $p=0.001)$.

Keywords: Type 2 diabetes mellitus; quality of life; antidiabetic prescribed; complication

\section{PENDAHULUAN}

Diabetes melitus tipe 2 (DM tipe 2) merupakan penyakit metabolik kronik dengan angka kejadian tinggi yang mengalami peningkatan dari tahun ke tahun ${ }^{1,2}$. Penyakit ini tidak dapat disembuhkan secara total, namun hanya dapat dikontrol sehingga memerlukan terapi seumur hidup 3 . Terapi yang digunakan adalah antidiabetik baik oral maupun insulin dengan mekanisme kerja yang berbeda-beda dalam mengontrol kadar glukosa darah ${ }^{4}$. Pemilihan terapi antidiabetik disesuaikan dengan kebutuhan dan kondisi klinik pasien berdasarkan algoritma terapi. Dimulai dari monoterapi antidiabetik oral, lalu terapi kombinasi antidiabetik serta penggunaan insulin intensif ${ }^{5}$.

Beberapa penelitian mengkaji perbandingan penggunaan jenis antidiabetik dalam meningkatkan kontrol glikemik dan pengaruhnya pada kualitas hidup. Penelitian tersebut menunjukkan bahwa rata-rata kualitas hidup pasien DM tipe 2 yang menerima terapi kombinasi insulin dengan oral lebih tinggi dibandingkan dengan pasien yang menerima monoterapi insulin dan monoterapi oral6,7. Sama halnya dengan penelitian lainnya, yang menyebutkan bahwa penggunaan kombinasi insulin dengan metformin pada pasien yang baru didiagnosis DM tipe 2 dengan kadar $\mathrm{HbA} 1 \mathrm{c}>7,5 \%$, dapat mengontrol glukosa darah dengan baik. Penggunaan kombinasi insulin dengan antidiabetik oral dapat mengurangi dosis insulin sekitar $46 \%$ sehingga dapat meminimalkan resiko terjadinya efek samping obat yang secara langsung berpengaruh terhadap peningkatan kualitas hidup ${ }^{8}$.

Berbeda dengan beberapa penelitian diatas, terdapat penelitian yang menunjukkan bahwa pasien DM tipe 2 yang menggunakan terapi insulin memiliki kualitas hidup yang lebih rendah pada domain fungsi fisik, fungsi sosial dan persepsi kesehatan secara umum dibandingkan dengan pasien yang menggunakan terapi antidiabetik oral.
Meskipun penggunaan insulin dapat mengontrol glukosa darah dengan baik, namun beberapa pasien mengalami efek negatif dari penggunaan insulin yaitu merasa takut, sakit, cemas dan tidak nyaman karena efek samping yang ditimbulkan yaitu hipoglikemia9. Selain insulin, terdapat beberapa efek samping antidiabetik oral yang kerap muncul misalnya metformin dapat menyebabkan gangguan gastrointestinal seperti mual, muntah, diare serta asidosis laktat sebesar 20-30\%10. Akarbose dapat menyebabkan perut kembung dan diare ${ }^{11}$. Golongan sulfonilurea dapat menimbulkan hipoglikemia, ruam kulit, mual, muntah, konstipasi dan sakit kepala ${ }^{12}$. Penggunaan antidiabetik dalam jangka waktu panjang dapat menimbulkan kondisi ketidaknyamanan dan risiko timbulnya efek samping obat sehingga dapat mempengaruhi kualitas hidup pasien13.

Pada perjalanan DM tipe 2, apabila kadar glukosa darah pasien tidak terkontrol dengan baik, maka akan meningkatkan risiko terjadinya komplikasi baik akut maupun kronis ${ }^{14}$. Komplikasi kronik yang sering dijumpai pada pasien DM tipe 2 yang menjalani terapi rawat jalan adalah komplikasi makrovaskuler (penyakit arteri koroner, arteri perifer, stroke) dan mikrovaskuler (neuropati, nefropati dan retinopati) ${ }^{15}$. Komplikasi menimbulkan masalah yang signifikan terhadap kualitas hidup serta peningkatan terjadinya mortalitas ${ }^{16}$. Terdapat penelitian di Indonesia yang menyebutkan bahwa pasien DM tipe 2 yang mengalami komplikasi menunjukkan nilai kualitas hidup yang rendah dibandingkan pasien tanpa komplikasi ${ }^{17}$. Selain itu terdapat penelitian lainnya yang menyebutkan bahwa kualitas hidup pasien DM tipe 2 dengan komplikasi baik mikrovaskuler maupun makrovaskuler lebih rendah dibandingkan pasien tanpa

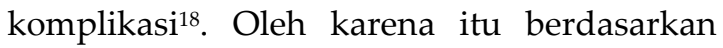
pemaparan hasil penelitian diatas, peneliti 
ingin mengetahui perbedaan kualitas hidup pasien DM tipe 2 berdasarkan pola peresepan antidiabetik dan terjadinya komplikasi Di Instalasi Rawat Jalan Poliklinik Penyakit Dalam RSUD Panembahan Senopati Bantul Yogyakarta.

\section{METODE}

\section{Rancangan penelitian}

Jenis penelitian ini adalah observational dengan rancangan cross sectional yang dilakukan pada bulan September 2017 Di Instalasi Rawat Jalan Poliklinik Penyakit Dalam RSUD Panembahan Senopati Bantul Yogyakarta. Penelitian ini telah memperoleh izin Komite Etik Fakultas Kedokteran Universitas Gadjah Mada (Ref: KE/FK/0654/EC/2017) dan izin penelitian RSUD Panembahan Senopati Bantul Yogyakarta (No: 070/2944). Rata-rata jumlah populasi pasien DM tipe 2 pada kunjungan rawat jalan tiap bulan adalah 800 pasien. Berdasarkan perhitungan sampel menggunakan rumus Taro Yamane dengan menggunakan tingkat presisi $0,07 \quad(7 \%)$, diperoleh jumlah sampel minimal yaitu 162 responden ${ }^{19}$. Untuk mengantisipasi data rekam medik pasien yang tidak lengkap maka peneliti menambah jumlah sampel $10-20 \%$, sehingga jumlah sampel yang dilibatkan dalam penelitian sebesar 200 responden. Kriteria inklusi penelitian meliputi pasien DM tipe 2 rawat jalan yang memperoleh obat antidiabetik minimal 3 bulan sebelum penelitian berlangsung, berusia $\geq 18$ tahun, menyetujui inform concent dan bersedia mengisi kuesioner penelitian sedangkan kiteria eksklusi yaitu kondisi umum pasien lemah, dalam kondisi hamil atau menyusui.

\section{Pengumpulan data}

Pengambilan sampel penelitian menggunakan teknik purposive sampling berdasarkan kriteria inklusi dan eksklusi penelitian. Pengambilan data kualitas hidup dilakukan secara concurrent melalui wawancara dengan pasien pada saat kontrol rutin atau saat menunggu pengambilan obat. Pasien DM tipe 2 yang bersedia menjadi responden mengisi kuesioner dan menandatangani inform consent yang telah disediakan. Data terkait pola peresepan dan gambaran komplikasi diperoleh dari rekam medik pasien.

\section{Alat ukur}

Kuesioner yang digunakan untuk mengukur kualitas hidup adalah Diabetes Quality of Life Clinical Trial Quessionaire (DQLCTQ) yang diperoleh dari adaptasi penelitian Shen $\mathrm{dkk}^{20}$. Di Indonesia kuesioner DQLCTQ digunakan pada penelitian Hartati ${ }^{21}$ dalam versi Bahasa indonesia dan telah dilakukan uji validasi dan reliabilitas dengan nilai $\alpha=0,82(>0,5)$. Kuesioner DQLCTQ terdiri dari delapan domain yang terdiri dari 57 macam pertanyaan. Kualitas hidup pasien dinilai dengan cara menghitung skoring data kuesioner, perhitungan rata-rata pada masingmasing domain dan total nilai kualitas hidup. Skor total secara keseluruhan antara nol (0) yang menunjukkan kualitas hidup terendah sampai 100 yang menunjukkan kualitas hidup tertinggi. Skor yang lebih tinggi menandakan status kesehatan yang lebih baik ${ }^{20}$.

\section{Analisis data}

Analisis data penelitian menggunakan Statistical Package for the Social Science (SPSS) software version 23. Data sosiodemografi, gambaran pola peresepan dan komplikasi digambarkan secara deskriptif. Analisis perbedaan kualitas hidup berdasarkan pola peresepan antidiabetik dan komplikasi menggunakan uji Kruskal Wallis, lalu selanjutnya dianalisis menggunakan uji post hoc dengan Mann Whitney.

\section{HASIL DAN PEMBAHASAN}

\section{A. Karakteristik demografi}

Karakteristik demografi pasien DM tipe 2 didominasi oleh jenis kelamin perempuan $(56,5 \%)$ dan umur $\geq 60$ tahun (59\%) yang dapat dilihat pada Tabel I. Beberapa penelitian menunjukkan bahwa jumlah pasien DM tipe 2 dengan jenis kelamin perempuan lebih tinggi dibandingkan laki-laki ${ }^{22,23}$. Hal ini disebabkan oleh faktor hormonal, peluang dalam kenaikan indeks masa tubuh yang lebih besar, risiko terkena penyakit jantung, terdapat fase 
Tabel I. Data Demografi Pasien DM Tipe 2

\begin{tabular}{lcc}
\hline Karakteristik Demografi & $\begin{array}{c}\text { Jumlah sampel } \\
(\mathbf{n}=\mathbf{2 0 0})\end{array}$ & $\begin{array}{c}\text { Persentase } \\
\text { (\%) }\end{array}$ \\
\hline Jenis kelamin & & \\
$\quad$ Perempuan & 113 & 56,5 \\
$\quad$ Laki-laki & 87 & 43,5 \\
Umur & & \\
$\quad<40$ tahun & 5 & 2,5 \\
$40-59$ tahun & 77 & 38,5 \\
$\geq 60$ tahun & 118 & 59 \\
Durasi mengidap & & \\
$<5$ tahun & 59 & 29,5 \\
$5-10$ tahun & 81 & 40,5 \\
$>10$ tahun & 60 & 30 \\
Penyakit penyerta & & \\
Terdapat penyakit penyerta & 168 & 84 \\
Tanpa penyakit penyerta & 32 & 16 \\
Pendidikan & & \\
SD & 41 & 20,5 \\
SMP & 21 & 10,5 \\
SMA & 97 & 48,5 \\
Perguruan tinggi & 41 & 20,5 \\
Pekerjaan & & \\
Bekerja & 101 & 50,5 \\
Tidak bekerja & 99 & 49,5 \\
\hline
\end{tabular}

menopause serta lebih mudah mengalami depresi ${ }^{24,25}$. Bertambahnya usia merupakan salah satu faktor penyebab risiko DM tipe 2 . Penurunan fungsi fisiologis tubuh menyebabkan gangguan pada fungsi endokrin dalam memproduksi insulin, peningkatan masa lemak tubuh dan terjadinya resistensi insulin ${ }^{26,27}$.

Terkait dengan durasi mengidap penyakit dan adanya penyakit penyerta, pada penelitian ini paling banyak pasien mengidap DM tipe 2 selama 5-10 tahun (40,5\%) dan sebesar $84 \%$ pasien mengalami penyakit penyerta. Penelitian menunjukkan bahwa pasien dengan durasi mengidap DM tipe 2 yaitu 5-15 tahun memiliki risiko tinggi terkena komplikasi baik akut maupun kronis ${ }^{28}$. Penyakit penyerta yang sering dijumpai pada pasien DM tipe 2 adalah hipertensi dan hiperlipidemia ${ }^{29}$. Berdasarkan tingkat pendidikan dan status pekerjaan, pasien yang terlibat dalam penelitian ini lebih banyak berpendidikan SMA $(48,5 \%)$ dan berstatus memiliki pekerjaan (50,5\%). Pendidikan pasien berkaitan dengan pengetahuan mengenai pengobatan dan kontrol glukosa darah $^{30,31}$. Dalam pekerjaan terdapat kondisi stress yang dapat menjadi faktor penyebab DM, karena berpotensi meningkatkan kadar glukosa darah dan resistensi insulin ${ }^{32}$.

\section{Gambaran pola peresepan antidiabetik}

Pola peresepan antidiabetik pasien DM tipe $2 \mathrm{Di}$ Instalasi Rawat Jalan RSUD Panembahan Senopati dikategorikan menjadi empat kelompok yaitu monoterapi oral, monoterapi insulin, kombinasi oral serta kombinasi oral dengan insulin yang ditampilkan pada Tabel II. Antidiabetik oral yang digunakan meliputi golongan biguanid yaitu metformin, golongan sulfonilurea yaitu glimepirid, glibenklamid, gliklazid dan 
Tabel II. Gambaran Pola Peresepan Obat Antidiabetik

\begin{tabular}{lcc}
\hline Pola Peresepan Antidiabetik & $\begin{array}{c}\text { Jumlah sampel } \\
(\mathbf{n = 2 0 0 )}\end{array}$ & $\begin{array}{c}\text { Persentase } \\
(\mathbf{\%})\end{array}$ \\
\hline Monoterapi oral & 24 & 12 \\
Monoterapi insulin & 30 & 15 \\
Kombinasi oral & 44 & 22 \\
Kombinasi oral dengan insulin & 102 & 51 \\
\hline
\end{tabular}

gliquidon, golongan inhibitor alfa glukosidase yaitu akarbose serta golongan thiazolidinedion yaitu pioglitazon. Penggunaan insulin meliputi golongan insulin kerja kombinasi (pre-mixed insulins) yaitu insulin aspart protamin $(70 \%) /$ insulin aspart $(30 \%)$ dan insulin lispro protamin $(50 \%) /$ insulin lispro $(50 \%)$, golongan insulin kerja cepat (rapid acting) yaitu insulin aspart dan glulisin, golongan insulin kerja lama (long acting) yaitu insulin detemir dan glargin.

Pada penelitian ini pola peresepan yang paling banyak digunakan adalah kombinasi antidiabetik oral dengan insulin (51\%). Terdapat beberapa penelitian yang sesuai dengan hasil penelitian ini, bahwa penggunaan kombinasi antidiabetik oral maupun kombinasi dengan insulin lebih besar dibandingkan monoterapi dalam mengontrol glukosa darah pasien ${ }^{33-35}$. Pemberian terapi antidiabetik pada pasien DM tipe 2 disesuaikan dengan kondisi klinik dan kebutuhan individual sesuai dengan pedoman terapi. Berdasarkan algoritma terapi, pemberian terapi dimulai dengan monoterapi, apabila target glukosa darah belum tercapai maka diberikan terapi kombinasi yang dimulai dengan kombinasi dua antidiabetik lalu dilanjutkan dengan kombinasi tiga antidiabetik atau penggunaan terapi insulin intensif 5 . Penggunaan terapi kombinasi antidiabetik diharapkan dapat mengontrol glukosa darah dengan lebih baik karena patofisiologi DM tipe 2 yang multifaktorial sehingga membutuhkan obat yang memiliki mekanisme kerja yang berbeda dan mampu bekerja sama dalam menurunkan dan mengontrol kadar glukosa darah ${ }^{36}$.

\section{Gambaran komplikasi}

Gambaran komplikasi pasien DM tipe 2 dibagi menjadi empat kelompok yang terdiri dari komplikasi mikrovaskuler, komplikasi makrovaskuler, komplikasi mikrovaskuler dan makrovaskuler serta tanpa komplikasi. Berdasarkan Tabel III, jumlah pasien DM tipe 2 yang mengalami komplikasi lebih sedikit $(36,5 \%)$ dibandingkan tanpa komplikasi (63,5\%). Terdapat penelitian yang mendukung hasil penelitian ini bahwa jumlah pasien DM tipe 2 tanpa komplikasi di Saudi Arabia lebih banyak dibandingkan pasien yang mengalami komplikasi ${ }^{37}$.

Pada penelitian ini komplikasi yang banyak dialami oleh pasien adalah komplikasi makrovaskuler (19,5\%). Hal ini sejalan dengan penelitian sebelumnya yang dilakukan di Korea dan Indonesia bahwa komplikasi yang kerap dijumpai pada pasien DM tipe 2 adalah komplikasi makrovaskuler ${ }^{38-40}$. Beberapa studi penelitian menunjukkan hasil yang berbeda yaitu jumlah pasien DM tipe 2 yang mengalami komplikasi mikrovaskuler lebih tinggi dibandingkan komplikasi makrovaskuler ${ }^{41-43}$. Komplikasi makrovaskuler yang terjadi pada penelitian ini meliputi Coronary Artery Disease (CAD), Chronic Heart Failure (CHF), stroke, Ischemic Heart Disease (IHD), Peripheral Arteri Disease (PAD), infark miokardial, Deep Vein Thrombosis (DVT) serta post ST-Elevation Myocardial Infarction (STEMI). Komplikasi mikrovaskuler meliputi neuropati dan nefropati. Komplikasi mikrovaskuler dan makrovaskuler pada penelitian ini terdiri dari komplikasi nefrologi dan CHF serta komplikasi nefrologi dan PAD. Manifestasi klinik DM tipe 2 ditandai dengan 
Tabel III. Gambaran komplikasi pasien DM tipe 2

\begin{tabular}{lcc}
\hline Komplikasi & $\begin{array}{c}\text { Jumlah sampel } \\
(\mathbf{n = 2 0 0 )}\end{array}$ & $\begin{array}{c}\text { Persentase } \\
\mathbf{( \% )}\end{array}$ \\
\hline Mikrovaskuler & 30 & 15 \\
Makrovaskuler & 39 & 19,5 \\
Mikrovaskuler dan Makrovaskuler & 4 & 2 \\
Tanpa Komplikasi & 127 & 63,5 \\
\hline
\end{tabular}

hiperglikemia. Pada perjalanan DM tipe 2, kondisi hiperglikemia yang berkepanjangan dan tidak terkontrol menyebabkan peningkatan jalur poliol, peningkatan pembentukan protein glikasi non enzimatik serta peningkatan proses glikosilasi itu sendiri, yang dapat menyebabkan peningkatan terjadinya stress oksidatif dan pada akhirnya menyebabkan terjadinya komplikasi baik akut maupun kronis. Komplikasi yang disebabkan oleh hiperglikemia dapat menyebabkan kerusakan pada pembuluh darah kecil seperti pada neuropati, nefropati, dan retinopati, dan pembuluh darah besar yaitu penyakit kardiovaskular dan serebrovaskular ${ }^{44}$. Berdasarkan laporan United Kingdom Prospective Diabetes Study (UKPDS), bahwa sebanyak 9\% pasien DM tipe 2 di Inggris, memiliki komplikasi mikrovaskular dalam waktu 9 tahun sejak di diagnosis dan sebanyak $20 \%$ pasien DM tipe 2 mengalami komplikasi makrovaskular. Komplikasi makrovaskuler menyebabkan kematian sebesar 59\% pada pasien DM tipe 2 di Inggris ${ }^{45}$.

\section{Analisis kualitas hidup berdasarkan pola peresepan dan komplikasi}

Pengukuran kualitas hidup menggunaan kuesioner DQLCTQ yang mencakup delapan domain yang meliputi fungsi fisik (physical fungtion), energi (energy), tekanan kesehatan (health distress), kesehatan mental (mental distress), kepuasan pribadi (satisfaction), kepuasan pengobatan (treatment satisfaction), efek pengobatan (treatment flexibility) dan frekuensi gejala penyakit (frequency of symptoms). Nilai rata-rata kualitas hidup 200 responden penelitian adalah $(65,7$ $(7,7)$ ) dengan rata-rata nilai domain fungsi fisik $(57,6(27,1))$, energi $(57,9(10,1))$, tekanan kesehatan $(87,6(10,2))$, kesehatan mental $(81,3$ $(10,3))$, kepuasan pribadi $(70,5(8))$, kepuasan pengobatan $(74,7(13,7))$, efek pengobatan $(46$ $(9,1))$ dan frekuensi gejala penyakit $(62,2(24))$. Pola peresepan dan komplikasi dalam penelitian ini memberikan pengaruh yang berbeda-beda dalam setiap domain yang diukur.

\section{Kualitas hidup berdasarkan pola peresepan}

Rata-rata nilai kualitas hidup tertinggi terdapat pada pasien DM tipe 2 yang memperoleh terapi kombinasi antidiabetik oral yang tersaji pada Tabel IV. Berdasarkan uji Kruskal Wallis perbedaan kualitas hidup antara keempat kelompok pola peresepan tidak berbeda secara signifikan $(p=0,057)$. Berbeda dengan hasil penelitian sebelumnya, bahwa pasien DM tipe 2 yang memperoleh monoterapi oral menunjukkan skor kualitas hidup yang lebih tinggi dibandingkan kombinasi oral. Pasien dengan monoterapi antidiabetik memiliki kontrol glikemik yang baik sehingga hanya membutuhkan satu macam obat untuk mengontrol glukosa darah. Potensial efek samping yang dirasakan minimal sehingga berdampak pada peningkatan kualitas hidup dibandingkan pasien yang menggunakan kombinasi dua hingga tiga antidiabetik untuk mengontrol glukosa darah ${ }^{46,47}$. Terdapat pula penelitian sebelumnya yang menunjukkan bahwa nilai kualitas hidup pasien yang menggunakan monoterapi insulin lebih tinggi dibandingkan pasien yang menggunakan kombinasi tiga antidiabetik oral ${ }^{40}$. Berdasarkan hasil studi sebelumnya, penggunaan insulin dapat mengontrol glukosa darah yang dibuktikan 
Tabel IV. Perbedaan kualitas hidup berdasarkan pola peresepan

\begin{tabular}{lccccc}
\hline \multirow{2}{*}{\begin{tabular}{c} 
Domain kualitas \\
\multicolumn{1}{c}{ hidup }
\end{tabular}} & \multicolumn{3}{c}{ Pola peresepan antidiabetik (rata-rata (SD)) } & \multirow{2}{*}{ Kombinasi } & \multirow{2}{*}{ Nilai p } \\
\cline { 2 - 5 } & Oral & Insulin & $\begin{array}{c}\text { Oral dengan } \\
\text { oral }\end{array}$ & $\begin{array}{c}\text { Oral dengan } \\
\text { insulin }\end{array}$ & \\
\cline { 2 - 5 } & $49,7(30,4)$ & $57,8(28,9)$ & $64,5(26,6)$ & $57,9(24,1)$ & 0,110 \\
Fisik & $56,3(10)$ & $60,8(11,8)$ & $56,4(10,7)$ & $57,3(8,3)$ & 0,557 \\
$\begin{array}{l}\text { Tekanan } \\
\text { kesehatan }\end{array}$ & $87,1(13,7)$ & $85,2(7,4)$ & $89,3(8,6)$ & $87,4(10,8)$ & 0,077 \\
Kesehatan mental & $79(11,7)$ & $81,5(12,6)$ & $84,1(9,9)$ & $80,7(9,7)$ & 0,331 \\
Kepuasan pribadi & $72,2(7,4)$ & $70,3(8,4)$ & $71,8(6,5)$ & $69,2(8,1)$ & 0,108 \\
Kepuasan & $82,1(9,4)$ & $79,1(12,2)$ & $75,9(12,7)$ & $70,3(13,7)$ & $0,000 *$ \\
pengobatan & $44,6(7,3)$ & $46,1(7,1)$ & $46,9(10,3)$ & $45,1(8,9)$ & 0,755 \\
Efek pengobatan & $71,2(11,6)$ & $66,1(11,5)$ & $69,3(12)$ & $65,1(12,6)$ & 0,075 \\
Frekuensi gejala & $66,1(7,2)$ & $66,4(7,9)$ & $68,1(5,9)$ & $65,2(6,4)$ & 0,057 \\
$\begin{array}{l}\text { Nilai kualitas } \\
\text { hidup }\end{array}$ & & & & & \\
\hline
\end{tabular}

Keterangan $:{ }^{*}=$ berbeda bermakna $(p<0,05)$

dengan penurunan kadar $\mathrm{HbA1c}$, sehingga secara tidak langsung berdampak positif pada peningkatan nilai kualitas hidup ${ }^{48}$.

Studi lain menyebutkan bahwa skor kualiatas hidup pasien dengan kombinasi insulin dengan oral menunjukkan hasil yang lebih tinggi dibandingkan monoterapi insulin ${ }^{7}$. Penelitian menunjukkan bahwa penggunaan kombinasi insulin dengan antidiabetik oral menunjukkan hasil klinis yang lebih baik karena dapat meningkatkan sel beta pankreas, mengurangi glukotoksisitas, mencegah kerusakan endotel dan menekan proses inflamasi sehingga dapat mempengaruhi kepuasan pengobatan yang berdampak pada peningkatan kualitas hidup ${ }^{49}$. Penggunaan kombinasi antidiabetik lebih dianjurkan daripada meningkatkan dosis obat karena dapat menimbulkan toksisitas dan efek samping obat. Terapi kombinasi menggunakan dua jenis antidiabetik memberikan manfaat yang lebih baik dalam mengontrol kadar glukosa darah, memperbaiki fungsi sel beta pankreas serta meningkatkan kualitas hidup. Hal ini disebabkan karena patofisiologi DM tipe 2 yang multifaktorial, sehingga membutuhkan terapi kombinasi dengan mekanisme kerja yang berbeda dalam mengontrol glukosa darah $^{36 .}$.

Pada domain fungsi fisik, pasien dengan monoterapi oral lebih terbatas dalam melakukan aktivitas atau pekerjaan seharihari, namun secara statistik tidak terdapat perbedaan yang signifikan $(\mathrm{p}=0,110)$. Berbeda dengan studi sebelumnya bahwa pasien dengan monoterapi baik insulin maupun oral dapat melakukan aktivitas dengan baik dibandingkan terapi kombinasi antidiabetik ${ }^{46,47}$. Pada domain energi, monoterapi oral dan kombinasi oral sering merasa lelah, kurang bersemangat serta kurang bertenaga/berenergi dalam melakukan kegiatan apapun yang diinginkan, namun tidak terdapat perbedaan yang signifikan $(p=0,557)$. Sejalan dengan hasil penelitian sebelumnya, pada domain energi pasien yang menerima monoterapi antidiabetik lebih merasa lelah dan kurang berenergi dalam menjalankan aktivitas ${ }^{17}$.

Pada domain tekanan kesehatan, kelompok monoterapi insulin kurang berbesar hati dalam menerima kondisi kesehatannya, merasa ketakutan, putus asa dalam menghadapi masalah serta frustasi karena penyakit DM yang dialaminya, namun tidak 
terdapat perbedaan yang signifikan $(p=0,077)$. Berbeda dengan studi sebelumnya, bahwa pasien yang menerima monoterapi oral menunjukkan nilai domain tekanan kesehatan yang lebih tinggi dibandingkan kombinasi antidiabetik ${ }^{46}$. Pada domain kesehatan mental, kelompok monoterapi insulin dan kombinasi oral lebih merasa tenang, damai, bahagia, tidak merasa cemas, ketakutan, sedih dan rendah hati dalam menghadapi penyakit DM, namun tidak terdapat perbedaan yang signifikan $(p=0,331)$. Penelitian terdahulu menyebutkan bahwa pasien dengan kombinasi antidiabetik menunjukkan nilai domain kesehatan mental yang lebih tinggi dibandingkan monoterapi antidiabetik ${ }^{46,47}$.

Pada domain kepuasan pribadi, kelompok monoterapi oral merasa puas terhadap keadaan yang dialami yaitu merasa bahwa penyakit DM yang dialami tidak membahayakan dirinya, puas terhadap waktu yang dihabiskan untuk memeriksakan diri ke dokter, dapat mengatur atau mengendalikan penyakit DM dengan menggunakan obat dan pola hidup yang baik, namun tidak terdapat perbedaan yang signifikan $(\mathrm{p}=0,108)$. Beberapa penelitian menunjukkan bahwa nilai domain kepuasan pribadi pasien dengan monoterapi antidiabetik lebih tinggi dibandingkan dengan kombinasi antidiabetik oral $^{7,17}$.

Pada domain efek pengobatan, kelompok monoterapi oral menunjukkan kurang merasakan efek pengobatan terkait penyakit DM tipe 2, namun secara statistika tidak terdapat perbedaan yang signifikan $(p=0,755)$. Sesuai dengan hasil penelitian sebelumnya bahwa pasien yang menerima monoterapi antidiabetik kurang merasakan efek pengobatan yang diterima ${ }^{17,46}$. Pada domain frekuensi gejala penyakit, kelompok monoterapi insulin dan kombinasi oral dengan insulin lebih sering mengalami gejala penglihatan kabur, mual, lemah, lesu, haus, mulut kering, sangat lapar, sering buang air kecil, serta sering merasa kesemutan pada tangan dan kaki, namun secara statistika tidak terdapat perbedaan yang signifikan $(\mathrm{p}=0,075)$. Penelitian sebelumnya menyebutkan bahwa pasien yang menggunakan kombinasi oral lebih sering mengalami gejala hiperglikemia7 ${ }^{7}$

Berdasarkan Tabel IV, dari kedelapan domain kualitas hidup, terdapat perbedaan yang signifikan $(p=0,000)$ pada domain kepuasan pengobatan. Berdasarkan uji post hoc dengan Mann Whitney terdapat perbedaan kualitas hidup pada kelompok monoterapi oral dengan kombinasi oral dan insulin $(\mathrm{p}=0,000)$ serta antara monoterapi insulin dengan kombinasi oral dan insulin $(p=0,002)$. Pada domain kepuasan pengobatan, pasien yang menerima monoterapi oral merasa penyakit DM yang dialami lebih terkontrol dengan menggunakan terapi yang dijalani, lebih merasa puas dengan pengobatan yang diterima serta memiliki harapan terhadap pengobatan di masa yang akan datang dalam memperbaiki kondisi diabetes yang dialami. Sejalan dengan penelitian sebelumnya, bahwa pasien yang memperoleh monoterapi antidiabetik lebih merasa puas dengan pengobatan yang diterima ${ }^{46,47}$.

\section{Kualitas hidup berdasarkan komplikasi}

Pasien DM tipe 2 tanpa komplikasi memiliki rata-rata nilai kualitas hidup yang lebih tinggi dibandingkan dengan adanya komplikasi yang disajikan pada Tabel V. Berdasarkan uji Kruskal Wallis tidak terdapat perbedaan kualitas hidup yang signifikan pada keempat kelompok komplikasi $(p=0,104)$. Hal ini sesuai dengan hasil penelitian sebelumnya yang menyebutkan bahwa kualitas hidup pasien DM tipe 2 yang mengalami komplikasi menunjukkan nilai yang lebih rendah dibandingkan pasien tanpa komplikasi ${ }^{50}$. Hal ini didukung oleh studi systematic review di Iran, yang menyatakan bahwa pasien DM tipe 2 tanpa komplikasi memiliki nilai kualitas hidup yang lebih tinggi dibandingkan pasien dengan komplikasi ${ }^{51}$.

Pada penelitian ini pasien DM tipe 2 dengan komplikasi mikrovaskuler memiliki nilai kualitas hidup yang paling rendah dibandingkan komplikasi lainnya. Hal ini sejalan dengan penelitian sebelumnya bahwa pasien DM tipe 2 di Yunani dan Saudi Arabia yang sebagian besar memiliki komplikasi 
mikrovaskuler (neuropati perifer dan retinopati) memiliki kualitas hidup rendah dibandingkan dengan komplikasi makrovaskuler dan tanpa komplikasi ${ }^{52,53}$. Pada Tabel V menunjukkan pasien tanpa komplikasi memiliki rata-rata nilai kualitas hidup yang tinggi pada hampir semua domain kecuali tekanan kesehatan, kepuasan pribadi dan efek pengobatan.

Pada domain fungsi fisik, terkait pengaruh penyakit DM, pasien dengan komplikasi mikrovaskuler dan makrovaskuler lebih terbatas dalam melakukan aktivitas atau pekerjaan sehari-hari, namun secara statistik tidak terdapat perbedaan yang signifikan $(p=0,125)$. Berbeda dengan penelitian terdahulu, yang menyebutkan bahwa pasien yang mengalami komplikasi makrovaskuler menunjukkan nilai domain fungsi fisik yang paling rendah, sehingga lebih terbatas dalam melakukan aktivitas sehari-hari ${ }^{17}$. Pada domain energi, pasien dengan komplikasi mikrovaskuler dan makrovaskuler serta komplikasi mikrovaskuler lebih sering merasa capek, lelah, kurang bersemangat serta kurang bertenaga/berenergi dalam melakukan kegiatan apapun yang diinginkan, namun tidak terdapat perbedaan yang signifikan $(p=0,085)$. Penelitian terdahulu menunjukkan bahwa pasien dengan komplikasi makrovaskuler serta pasien dengan komplikasi mikrovaskuler dan makrovaskuler merasa lebih sering capek, lelah dan kurang berenergi dalam melakukan kegiatan ${ }^{17}$.

Pada domain tekanan kesehatan, pasien dengan komplikasi mikrovaskuler kurang merasa berbesar hati dalam menerima kondisi kesehatannya, merasa takut dan frustasi karena penyakit diabetes yang dideritanya serta putus asa dalam menghadapi masalah, namun tidak terdapat perbedaan yang signifikan $(p=0,144)$. Berbeda dengan penelitian sebelumnya bahwa pasien yang mengalami komplikasi mikrovaskuler dan makrovaskuler merasa takut dan frustasi karena penyakit diabetes yang dideritanya ${ }^{17}$. Pada domain kepuasan pribadi, pasien dengan komplikasi makrovaskuler dan mikrovaskuler lebih merasa puas terhadap keadaan yang dialami, merasa bahwa penyakit DM tipe 2 yang dialami tidak membahayakan dirinya, puas terhadap waktu yang dihabiskan untuk memeriksakan diri ke dokter, dapat mengatur atau mengendalikan diabetes dengan menggunakan obat dan pola hidup yang baik, namun secara statistik tidak terdapat perbedaan yang signifikan $(p=0,488)$. Lain halnya dengan penelitian sebelumnya bahwa pasien yang mengalami komplikasi mikrovaskuler dan makrovaskuler merasa tidak puas dengan penyakit DM tipe 2 yang dialami karena dapat membahayakan dirinya ${ }^{17}$.

Pada domain kepuasan pengobatan, pasien dengan komplikasi makrovaskuler dan mikrovaskuler merasa tidak terkontrol dengan menggunakan terapi yang dijalani, merasa tidak puas dengan pengobatan yang diterima serta kurang memiliki harapan terhadap pengobatan di masa yang akan datang dalam memperbaiki kondisi diabetes yang dialami, namun tidak terdapat perbedaan yang signifikan $(p=0,850)$. Pada domain efek pengobatan, pasien DM tipe 2 dengan komplikasi mikrovaskuler kurang merasakan efek pengobatan terkait penyakit DM tipe 2, namun tidak terdapat perbedaan yang signifikan $(p=0,211)$. Hasil penelitian terdahulu memaparkan bahwa nilai domain kepuasan pengobatan dan domain efek pengobatan pada pasien yang mengalami komplikasi makrovaskuler paling rendah dibandingkan kelompok lainnya ${ }^{17}$.

Pada domain frekuensi gejala, pasien dengan komplikasi makrovaskuler serta pasien dengan komplikasi makrovaskuler dan mikrovaskuler sering mengalami gejala penglihatan kabur, mual, lemah, lesu, haus, mulut kering, sangat lapar, sering buang air kecil, serta sering merasa kesemutan pada tangan dan kaki dibandingkan kelompok lainnya, namun tidak terdapat perbedaan yang signifikan $(p=0,835)$. Sejalan dengan hasil penelitian sebelumnya, bahwa pasien yang mengalami komplikasi makrovaskuler dan mikrovaskuler lebih sering mengalami gejala hiperglikemia ${ }^{17}$. 
Pande Made Desy Ratnasari, et al

Tabel V. Perbedaan kualitas hidup berdasarkan komplikasi

\begin{tabular}{lccccc}
\hline \multicolumn{1}{c}{$\begin{array}{c}\text { Domain } \\
\text { Kualitas }\end{array}$} & \multicolumn{4}{c}{ Jenis Komplikasi (rata-rata (SD)) } & \\
\cline { 2 - 5 } & $\begin{array}{c}\text { Mikrovasku } \\
\text { ler }\end{array}$ & $\begin{array}{c}\text { Makrovasku } \\
\text { ler }\end{array}$ & $\begin{array}{c}\text { Mikrovaskuler } \\
\text { dan } \\
\text { Makrovaskuler }\end{array}$ & $\begin{array}{c}\text { Tanpa } \\
\text { komplikasi }\end{array}$ & Nilai p \\
\hline $\begin{array}{l}\text { Fisik } \\
\begin{array}{l}\text { Energi } \\
\text { Tekanan }\end{array}\end{array}$ & $50,6(27,6)$ & $55,9(23,4)$ & $45,9(37,6)$ & $61,5(27)$ & 0,125 \\
$\begin{array}{l}\text { kesehatan } \\
\text { Kesehatan } \\
\text { mental }\end{array}$ & $54,9(9,7)$ & $56,3(9,1)$ & $53(10)$ & $59,1(10,2)$ & 0,085 \\
$\begin{array}{l}\text { Kepuasan } \\
\text { pribadi }\end{array}$ & $76,6(9,8)$ & $88,5(8,9)$ & $87,5(14)$ & $88,2(10,6)$ & 0,144 \\
$\begin{array}{l}\text { Kepuasan } \\
\text { pengobatan }\end{array}$ & $74,3(12,6)$ & $73,8(14,3)$ & $65,3(21,9)$ & $75(13,6)$ & 0,850 \\
$\begin{array}{l}\text { Efek } \\
\text { pengobatan }\end{array}$ & $43,5(8,9)$ & $44,7(7,5)$ & $48(10,5)$ & $47,2(9,6)$ & 0,211 \\
$\begin{array}{l}\text { Frekuensi } \\
\text { gejala }\end{array}$ & $67,5(12,2)$ & $66,2(10,2)$ & $67,9(6,3)$ & $68,1(12,5)$ & 0,835 \\
$\begin{array}{l}\text { Nilai kualitas } \\
\text { hidup }\end{array}$ & $63,8(7,3)$ & $65,9(5,3)$ & $64,4(7,8)$ & $67,5(6,9)$ & 0,104 \\
\hline
\end{tabular}

Keterangan $:{ }^{*}=$ berbeda bermakna $(\mathrm{p}<0,05)$

Pada delapan domain kualitas hidup, terdapat perbedaan yang signifikan $(p=0,003)$ pada domain kesehatan mental. Berdasarkan uji post hoc dengan Mann Whitney terdapat perbedaan kualitas hidup antara komplikasi makrovaskuler dengan komplikasi mikrovaskuler $(\mathrm{p}=0,011)$ dan antara komplikasi mikrovaskuler dengan tanpa komplikasi $(p=0,001)$ Pasien dengan komplikasi makrovaskuler dan tanpa komplikasi lebih merasa tenang, damai, bahagia, tidak merasa cemas, takut, sedih dan redah hati dalam menghadapi penyakit diabetes dibandingkan kelompok lainnya. Penelitian sebelumnya yang dilakukan di Indonesia menyebutkan bahwa pasien dengan komplikasi mikrovakuler merasa kurang bahagia, cemas, ketakutan dan sedih dalam menghadapi penyakit diabetes yang dideritanya ${ }^{17}$. Didukung oleh penelitian lainnya bahwa pasien DM tipe 2 yang mengalami komplikasi mikrovaskuler dan makrovaskuler cenderung mengalami depresi, cemas dan merasakan rasa nyeri akibat komplikasi yang dialami sehingga dapat berdampak pada penurunan kualitas hidup pasien ${ }^{54,55}$. Studi lain menyatakan bahwa seseorang yang menderita DM dalam jangka waktu yang lama memiliki tingkat kecemasan yang tinggi, sehingga berdampak pada penurunan kualitas hidup ${ }^{56}$.

Keterbatasan dalam penelitian ini adalah terdapat beberapa variabel yang tidak dapat dikendalikan oleh peneliti yang dapat mempengaruhi hasil analisis seperti kepatuhan pengobatan, aspek sosial dan ekonomi, diet, aktivitas fisik dan gaya hidup pasien. Namun, hasil penelitian ini dapat memberikan gambaran mengenai gambaran kualitas hidup pasien yang dapat dipengaruhi oleh beberapa hal yaitu kondisi pasien, peresepan antidiabetik dan adanya komplikasi serta penelitian ini dapat memberikan informasi untuk penelitian selanjutnya. 


\section{KESIMPULAN}

Hasil penelitian menunjukkan sebesar $48,5 \%$ pasien DM tipe 2 memperoleh peresepan kombinasi antidiabetik oral dengan insulin. Komplikasi yang banyak diderita pasien adalah makrovaskuler (19,5\%). Ratarata nilai kualitas hidup pasien DM tipe 2 pada penelitian ini adalah 65,7. Terdapat perbedaan kualitas hidup berdasarkan peresepan antidiabetik pada domain kepuasan pengobatan $(p=0,000)$ antara kelompok monoterapi oral dengan kombinasi oral dan insulin $(p=0,000)$ serta monoterapi insulin dengan kombinasi oral dan insulin $(p=0,002)$. Terdapat perbedaan kualitas hidup berdasarkan komplikasi pada domain kesehatan mental $(p=0,003)$ antara komplikasi makrovaskuler dengan mikrovaskuler $(\mathrm{p}=0,011) \quad$ serta antara komplikasi mikrovaskuler dengan tanpa komplikasi $(\mathrm{p}=0,001)$.

\section{UCAPAN TERIMA KASIH}

Terima kasih kepada berbagai pihak yang telah membantu jalannya penelitian ini yaitu responden penelitian serta RSUD Panembahan Senopati Bantul Yogyakarta.

\section{DAFTAR PUSTAKA}

1. Gregg EW. The Changing Tides of the Type 2 Diabetes Epidemic d Smooth Sailing or Troubled Waters Ahead? Kelly West Award Lecture 2016. Diabetes Care. 2017;40:1289-1297.

2. Ogurtsova K., Rocha JD., Huang Y., Linnenkamp U., Guariguata L. IDF Diabetes Atlas: Global estimates for the prevalence of diabetes for 2015 and 2040. Diabetes Res Clin Pract. 2017;128:40-50.

3. Inzucchi SE., Bergenstal RM., Buse JB.,

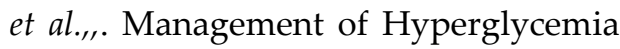
in Type 2 Diabetes, 2015: A PatientCentered Approach: Update to a Position Statement of the American Diabetes Association and the European Association for the Study of Diabetes. Diabetes Care. 2015;38(1):140-149.

4. Davies M., Alessio DAD., Fradkin J,
Kernan WN., Mathieu C. Management of hyperglycaemia in type 2 diabetes, 2018. A consensus report by the American Diabetes Association (ADA) and the European Association for the Study of Diabetes (EASD). Diabetologia. 2018.

5. American Diabetes Association. Standar of Medical Care in Diabetes2018. Clin Diabetes. 2018;36(1):14-37.

6. Hayek AA Al., Robert AA., Saeed A Al., Alzaid AA., Sabaan FS Al. Factors Associated with Health-Related Quality of Life among Saudi Patients with Type 2 Diabetes Mellitus: A Cross-Sectional Survey. Diabetes Metab J. 2014;38:220229.

7. Perwitasari DA., Adikusuma W., Rikifani S., Supadmi W. Quality of Life and Adherence of Diabetic Patients in Different Treatment Regimens Kualitas Hidup dan Kepatuhan Pasien Diabetes Melitus dengan Pengobatan yang Berbeda. Indones $J$ Clin Pharm. 2014;3(4):107-113.

8. Goudswaard A., Furlong N., Rutten G., Stolk R, Valk G. Review: Insulin monotherapy and insulin combined with oral hypoglycemic agents provide similar glycemic control Review : Shortacting insulin analogues reduce glycosylated hemoglobin more than regular human insulin but only in adults with type 1 diabetes. Cochrane Database Syst Rev. 2005;142(3):62-63.

9. Sepulveda E., Poínhos R., Pais-ribeiro J., Freitas P., Carvalho D. Health-related quality of life in type 1 and type 2 diabetic patients in a Portuguese central public hospital. Diabetes Metab Syndr Obes. 2015;8:219-226.

10. Fatima M., Sadeeqa S., Ur S., Nazir R. Metformin and its gastrointestinal problems: A review . Biomed Res. 2018;29(11):2285-2289.

11. Gao X., Cai X., Yang W., Chen Y., Han $X ., \quad J i$ L. Meta-analysis and critical review on the ef fi cacy and safety of alpha-glucosidase inhibitors in Asian 
and non-Asian populations. J Diabetes Investig. 2018;9(2):321-331.

12. Yadav M., Saraswat N., Wal P., Rai A., Singh D. A Comparative Study of Drug Interaction and Side Effect of Drug for Treatment of Diabetes Mellitus: A Review. Int Res J Pharm. 2018;9(6):14-16.

13. Akinci F., Yildirim A., Go $\mathrm{H}$. Assessment of health-related quality of life ( HRQoL ) of patients with type 2 diabetes in Turkey. Diabetes Res Clin Pract. 2008;79:117-123.

14. Chappidi M., Shivananjiah S., Thirthahalli C., et al., Complications of diabetes mellitus among patients attending the out- patient department of a tertiary care hospital. Int J Community Med Public Heal. 2018;5(1):341-348.

15. Liu Z., Fu C., Wang W., Xu B. Prevalence of chronic complications of type 2 diabetes mellitus in outpatients a cross-sectional hospital based survey in urban China. Health Qual Life Outcomes. 2010;8(62):1-9.

16. Younis B Bin., Arshad R., Yousuf H., Salman F., Masood J., Khurshid S. Impact of type 2 diabetes mellitus on quality of life in people with diabetes presenting to a specialist diabetes clinic. Turkish J Med Sci. 2017;47:123-126.

17. Andayani TM. Health-Related Quality of Life of Type 2 Diabetes Mellitus Outpatients at Dr. Sardjito Hospital, Yogyakarta , Indonesia: An InsulinBased Therapy Approach Kualitas Hidup Terkait Kesehatan dari Pasien Diabetes Melitus Tipe 2 di Rumah Sakit Umum Pusat Dr. Indones J Clin Pharm. 2017;6(4):231-239.

18. Prajapati VB., Blake R., Acharya LD., Seshadri S. Assessment of quality of life in type II diabetic patients using the modified diabetes quality of life (MDQoL)-17 questionnaire. Brazilian J Pharm Sci. 2015;53(4):1-9.

19. Habib M., Pathik B., Maryam H. Research Methodology - Contemporary Practices: Guidelines for Academic Researchers. Cambridge Scholars
Publishing; 2014.

20. Shen W., Kotsanos JG., Huster WJ., Mathias SD., Andrejasich CM., Patrick DL. Development and validation of the diabetes quality of life clinical trial questionnaire. Med Care. 1999;37(4):4566.

21. Hartati T. Kualitas Hidup Penderita DM Tipe 2: Perbandingan Antara Penderita Kadar Gula Darah Terkendali dan Tidak Terkendali [tesis]. 2003.

22. Lu Y., Wang N., Chen Y., et al., Healthrelated quality of life in type-2 diabetes patients : a cross-sectional study in East China. BMC Endocr Disord. 2017;17(38):1-7.

23. Hestiana D. Jurnal of Health Education. J Heal Educ. 2017;2(2):138-145.

24. Harreiter J., Kautzky-willer A., Kautzky-willer A. Sex and Gender Differences in Prevention of Type 2 Diabetes. Front Endocrinol (Lausanne). 2018;9(5):1-15.

25. Nishtar S. Diabetes is a serious women's health issue. Diabetes Voice. 2017;64(3):45.

26. Lascar N., Brown J., Pattison H., Barnett AH., Bailey CJ., Bellary S. Type 2 diabetes in adolescents and young adults. LANCET Diabetes Endocrinol. 2018;6(1):69-80.

27. Nandimath V., Swamy C., Nandimath S., Jatti G., Jadhav S. Evaluation of certain risk factors of type 2 diabetes mellitus : a case control study. Int J Med Sci Public Heal. 2016;5(7):3-8.

28. Al-saeed AH., Constantino MI., Molyneaux L., et al., An Inverse Relationship Between Age of Type 2 Diabetes Onset and Complication Risk and Mortality: The Impact of Youth Onset Type 2 Diabetes. Diabetes Care. 2016:1-7.

29. Song Y, Liu X., Zhu X., et al., Increasing trend of diabetes combined with hypertension or hypercholesterolemia : NHANES data analysis 1999-2012. Sci Rep. 2016;6(1):1-9.

30. Kassahun T., Gesesew H., Mwanri L., 
Eshetie T. Diabetes related knowledge, self-care behaviours and adherence to medications among diabetic patients in Southwest Ethiopia: a cross-sectional survey. BMC Endocr Disord. 2016;16(1):1-11.

31. Isnaini N., Ratnasari. Faktor risiko mempengaruhi kejadian Diabetes mellitus tipe dua Risk factors was affects of diabetes mellitus type 2. J Keperawatan dan Kebidanan Aisyiyah. 2018;14(1):59-68.

32. Falco G., Pirro P., Castellano E., M A., Borretta G., Gianotti L. The Relationship between Stress and Diabetes Mellitus. J Neurol Psychol. 2015;3(1):1-7.

33. Faridah IN., Dewintasari V. Quality of Life Analysis In Diabetes Mellitus Type 2 Patients Using Monotherapy and Combination Treatment of Medicine. Indones J Pharm. 2017;28(2):119.

34. Prachi D., Chirag D., Aarti P., Desai S. A Drug Prescribing Pattern Study in Diabetes Mellitus: An Outpatient Study. J Pharm Sci Biosci Res. 2015;5(1):115-118.

35. Rani .J, Reddy S. Prescribing pattern of antidiabetic drugs in urban population of Hyderabad. Natl J Physiol Pharm Pharmacol. 2015;5(1):5.

36. Soelistijo .S, Novida H., Rudijanto A., Soewondo P., Suastika K., Manaf A. Konsensus Pengelolaan Dan Pencegahan Diabetes Melitus Tipe 2 Di Indonesia 2015. Pengurus Besar Perkumpulan Endokrinologi Indonesia (PB PERKENI); 2015.

37. Siddiqui MA., Ul A., Siddiqui H., Rwelly F., Clay A. Frequency of diabetes, complications and vascular risk factors in male and female population of Al-Jouf, Saudi Arabia. Int J Med Dev Ctries. 2018;2(1):27-32.

38. Kim JH., Kim DJ., Jang HC., Choi SH. Epidemiology of Micro- and Macrovascular Complications of Type 2 Diabetes in Korea. Diabetes Metab J. 2011;35:571-577.

39. Rhee SY., Chon S., Kwon MK., et al.,
Prevalence of Chronic Complications in Korean Patients with Type 2 Diabetes Mellitus Based on the Korean National Diabetes Program. Diabetes Metab J. 2011;35(5):504.

40. Andayani TRIM., Izham M., Ibrahim M., Asdie AH. International Journal of Pharmacy and Pharmaceutical Sciences. 2010:139-145.

41. Maniarasu K., Muthunarayanan L. Prevalence of Certain Chronic Complications of Diabetes among Type 2 Diabetic Patients in Rural Population of Kancheepuram District, Tamil NaduA Cross Sectional Study. Int J Med Public Heal. 2017;7(1):41-46.

42. Zhuo X., Zhang P., Hoerger TJ. Lifetime Direct Medical Costs of Treating Type 2 Diabetes and Diabetic Complications. Am J Prev Med. 2013;45(3):253-261.

43. Selim S., Abougalambou .I, Hassali MA., Azhar S., Sulaiman S., Abougalambou AS. Prevalence of Vascular Complications among Type 2 Diabetes Mellitus Outpatients at Teaching Hospital in Malaysia. J Diabetes Metab. 2011;2(1):2-5.

44. Jung HS. Review Article Clinical Implications of Glucose Variability: Chronic Complications of Diabetes. Endocrinol Metab. 2015;30:167-174.

45. Group UPDS (UKPDS). Intensive blood-glucose control with sulphonylureas or insulin compared with conventional treatment and risk of complications in patients with type 2 diabetes (UKPDS 33). Lancet. 1998;352(9131):837-853.

46. Sari R., Thobari .J, Andayani T. Evaluasi Kualitas Hidup Pasien Diabetes Melitus Tipe 2 yang diterapi Rawat Jalan dengan Anti Diabetik Oral Di Rsup Dr. Sardjito. J Manaj dan Pelayanan Farm. 2011;1(1):35-42.

47. Adikusuma W., Perwitasari D., Supadmi W. Pengukuran Kualitas Hidup Pasien Diabetes Melitus Tipe 2 yang Mendapat Antidiabetik Oral Di Rumah Sakit PKU Muhammadiyah 
Bantul Yogyakarta. J Ilm Ibnu Sina. 2016;1(1):1-8.

48. Lau ANC., Tang T., Pharmd HH., Thorpe K, Mhsc CHYY. Initiating insulin in patients with type 2 diabetes. Can Med Assoc J. 2012;184(7):767-776.

49. Owens DR. Clinical Evidence for the Earlier Initiation of Insulin Therapy in Type 2 Diabetes. Diabetes Technol Ther. 2013;15(9):776-785.

50. Nasralla Saleh MS., Alwahedi Z. Quality of Life Predictors and Glycemic Control among Type 2 Diabetic Patients Attending Primary Health Care Centers in Qatar. Prim Heal Care Open Access. 2016;6(2):1-5.

51. Kiadaliri AA., Najafi B., Mirmalek-Sani M. Quality of life in people with diabetes: a systematic review of studies in Iran. $J$ Diabetes Metab Disord. 2013;12(1):54.

52. Lyrakos G., Hatziagelaki2 E., Damigos D., Papazafiropoulou A., Bousboulas S., Batistaki C. Predictors of health-related quality of life in Diabetic Neuropathy type II diabetic patients in Greece. Heal Sci J. 2013;7(3):327-341.

53. Al-Shehri FS. Quality of Life among Saudi Diabetics. J Diabetes Mellit. 2014;4(3):225-231.

54. Lindsay G., Inverarity K., McDowell JRS. Quality of Life in People with Type 2 Diabetes in Relation to Deprivation, Gender, and Age in a New CommunityBased Model of Care. Nurs Res Pract. 2011;2011:1-8.

55. Redekop W., Koopmanschap M., Stolk R., Rutten G., Niessen L. Health-Related Quality of Life and Treatment Satisfaction in Dutch Patients With Type 2 Diabetes. Diabetes Care. 2002;25(3):458-463.

56. Claudia A., Maia CDO., Braga ADA., et al., Comorbidity of Depression and Anxiety : Association with Poor Quality of Life in Type 1 and 2 Diabetic Patients. Clin Pract Epidemiol Ment Heal. 2013;9:136-141. 